\title{
Hiking in the landscape - the history of Europeans' linkage to the landscape by hiking
}

\author{
Teresa Lúcio de Sales, José Castro*, $\mathrm{M}^{\mathrm{a}}$ Graça Saraiva**, Teresa Pinto-Correia***, \\ University of Algarve, Portugal, Polytechnic Institute of Bragança, Portugal*, \\ Faculty of Architecture of University of Lisboa, Portugal**, University of Évora, Portugal ***
}

\begin{abstract}
: since remote times, man has hiked in the landscape, establishing bonds of communication and interconnection between two or more points. Hiking along trails is the means of escape for man, causing changes in the landscape, and making known sites and places. In this paper, the history of the dynamics established between the act of walking and the landscape, along with the changes in society (predominantly since the $18^{\text {th }}$ century), are presented. The existence of paths in nature is older than the very existence of mankind itself. The act of walking has always been associated with the history of man, who has hiked in the landscape looking for food, making pilgrimages, marketing products, promoting sustainable mobility, tourism and healthy recreation, and contributing to the improvement of the population's quality of life. There is a special connection to the landscape by walking. The paths are areas marked by time and by society. They are understood as a way of reading the landscape. The act of walking is associated with an art in which the pleasure is rather in sensations of the soul [37]. When we walk, we are exclusively dependent on ourselves and completely free to observe and appreciate the landscape as best suits us and with a complete tranquility [30; 37]. Knowledge of the landscape involves movement, and the best form of perceiving and establishing a close relationship with that landscape is walking. Nowadays, there is a significant increase in adherence to outdoor activities, especially walking. People are looking for new ways of being in contact with nature. A restorative effect of nature on man is, indeed, one of the fundamental aspects of this increased demand, and people walk for different reasons. Hiking in the natural landscape assumes a great importance for the maintenance of a healthy body and mind. It is important that we develop future research to improve our knowledge not only about the influence of walking in the natural landscape, related especially to the benefits it has on man's creativity, but also to improve the knowledge about how to combine modern life with the benefits of walking in nature.
\end{abstract}

Keywords: walking and hiking, paths, landscape, well-being, tourism and recreation in nature

\section{Introduction}

To hike in the landscape means to establish a relationship of thoughts and sensations with that landscape, resulting in an intuitive mental representation that is derived from the knowledge and experience of the observer. The act of walking is as ancient as humanity itself [23]. However, the motivations for walking in and amongst landscapes have changed through the centuries, fundamentally related to the evolution of society $[3 ; 9 ; 23 ; 32 ; 39]$.

Since the end of the last century, the demand for "natural" areas in which to practice outdoor activities (and, specifically, walking) has been on the rise. Footpaths are becoming increasingly popular, mainly to urban people, which has led to the increasing deployment of both small and large paths $[4 ; 15 ; 20$; $33 ; 44]$. In recent decades, several studies have related the importance of the act of walking with diverse goals: such as well-being; environmental awareness; tourism; a better knowledge of history; the enhanced process of thought and creativity; the understanding of the process of study, analysis and design of the landscape; as well as how the act of walking can generate knowledge $[10 ; 14 ; 21 ; 22 ; 25 ; 38 ; 39 ; 41]$. This paper will explore the relationships between the dynamics of the act of walking and the landscape. Initially, it will consider the history of landscape hikes alongside the changes in society, mainly since the $18^{\text {th }}$ century. Subsequently, it will explore our connection to the landscape by walking, and will conclude with reflections on the growing interest in present motivations to walk in the landscape.

\section{History of landscape hikes}

The existence of paths in nature is older than the very existence of mankind itself. In search of food, animals have always travelled through the territory, leaving their marks on the ground. From the beginning, human beings walked through the landscape, defining along the way their relationship with nature. In fact, the act of walking has always been associated with the history of man (being inseparable from the history of thought) who has hiked in the landscape looking for food, making pilgrimages, marketing products, conquering land, etc. $[3 ; 9 ; 37 ; 39]$. As hunter, man hiked in nature in search of sustenance, leaving only the marks of his feet. According to the geographer Archer Butler Hulbert, many of the paths most used by Native Americans on their long-distance travels were originally made by bison. These Native Americans were traders, hunters, curious travelers or nomads [23]. As a pastoralist nomad, man became more connected with the cyclical movements of animals, particularly through the 
practice of transhumance, and pathways developed in large open spaces. It can be said that the nomadic space is the path itself, and the "nomad city" is a winding line drawn by several points in movement. It is along the path that the life of the community develops, and the area which the path wends through (and the path itself) is assumed as a symbolic space [9].

In the Middle Ages and the Renaissance, trade and spiritual routes traced lines in the landscape, marking the trajectories of traders and pilgrims, many of whom hiked thousands of kilometers - either looking for new markets or seeking spirituality, making legendary journeys in the process. Trade routes seem to have existed since the first villages of Lower Mesopotamia, and, throughout the ages, many of these routes emerged in different territories, "drawing" on the ground numerous lines that led traders to their destinations [9]. Examples of such are the Silk Route and the Spice Route, both of which linked several empires, as well as major trading points, from Asia to Europe. Regarding pathways related to spirituality, it is important to mention the Via Francigena which was, in the Middle Ages, the largest pilgrimage route to connect Rome to the North, passing through Switzerland, France and England. Alongside Rome and Jerusalem, Santiago de Compostela is one of the main destinations of all the Christian pilgrimages, and its number of pilgrims peaked precisely during the Middle Ages. Pilgrimage is a vital part of many religions: Muslims who journey to Mecca; Hindus who cross their land to reach the banks of the Ganges [9; 22].

As time passed, the act of walking ceased to be essentially a kind of obligation, a necessity connected to everyday life. Instead it became an activity related to the enjoyment of nature. If initially it was mainly members of the clergy and the nobility who walked in the gardens and avenues, quickly this activity began to extend out to the middle classes, who were in full ascension during the $17^{\text {th }}$ and $18^{\text {th }}$ centuries [37] It was during the last decades of the 18 th century that the organized practice of walking tours was initiated, originally in England, especially by and for families. This interest for organized tours continued to develop throughout the $19^{\text {th }}$ century, catching on across northern and central Europe [4]. The pathways, walked in an informal manner, stretched forth into the countryside, through valleys and hills [37]. It was also at this time that walking began to be enjoyed, undertaken for its own sake, and for the heady combination of new emotions and sensations one can experience when, for example, climbing a mountain. These are paths of discovery into unknown environments.

According to Braga [4], the deployment of the first landmark footpath began towards the end of the 1940s and the start of the 1950s. In Portugal, this kind of footpath began to appear in the 1980s, and its increase was seen throughout the 1990s. Today, 267 footpaths (246 small routes and 21 great routes) are currently registered and approved by the Camping and Mountaineering Federation of Portugal [8].

On the other hand, since the last decades of the $20^{\text {th }}$ century, there has appeared another kind of footpath - known as Green Ways - which are paths related to the deactivated sections of railway lines. With its roots in the United States of America, this new concept grew from a movement called "Rails-to-Trails". The purpose was to constitute a strategy that promotes sustainable mobility and rural development, active tourism and healthy recreation, and contributes to the improvement of the quality of life of the population $[1 ; 17]$.

Following the development and the interest seen in the Green Ways, there came the idea to connect all the countries in Europe in a similar fashion, and the European Rambler's Association was founded in 1969, concerned with the marking of European long-distance paths across Europe (E-Paths). In the 21st century, European countries are now linked by 12 footpaths that cross Europe from north to south and east to west [16], in addition to numerous national, regional and local footpath routes.

\section{Connecting to the landscape by walking}

"It is not enough to read many descriptions about nature to be able to take advantage of its influence; the descriptions are not the same thing as itself, (...)" [37, 81].

Through hiking between points and areas, the walker appreciates and identifies the cultures and societies which he moves through, as well as the different landscapes which, with their wisdom, these cultures and societies have built.

The sequence of images that are being visualized allows the walker to anticipate the elements that identify themselves with: the evolution of humanity and society, the ecosystems, the landscape structures, and the stories they all tell, i.e., the landscape is strongly determined by the observer, through experience, perceptions and representation $[19 ; 9 ; 24$; 28]. The paths are areas marked by time and by society. While imagistic and symbolic of a society, the paths condense a whole imaginary universe, composed of speeches, memories and emotions, that cross, develop and symbolically structure an area. They appear as strategic places of observation and experience, where dialogues are "produced", many of which surprise us with their spontaneity. They lead man through the landscape and appear as an interaction between him and nature. They are understood as a way of reading the landscape, by offering closer contact with the surrounding environment and by allowing a multiplicity of points 
of view to be found, in accordance with the knowledge and experience of the walker and observer [9; 29]. There is a clear relationship between pathways and landscape, in which the paths are an integral part of the same and allow its reading. "Walking the landscape is more than an alternative to intellectual knowledge: it is essential to knowing" [38, p.10].

The paths appear as a privileged place for an exchange of flows of disciplinary knowledge and constitute places of reference and learning.

"Experiencing the landscape involves movement. And there is no better way to experience landscape than by walking, which not only involves visual experience, but rhythm, kinesthesia, balance, and so forth" [45, p.96]. The perception that the user has of the landscape is also determined by how the paths themselves allow their viewing.

In this context, the landscape can present itself in different forms, depending on the observer. Pursuing this line of thought, it is interesting to refer to the interpretation of landscape made by a group of experts who crossed continental Portugal through "Two Lines" [13], initially imagined, and implemented in the territory along the lines of existing communications - one line which follows the coast and another which runs along the border of Portugal with the Spanish territory. Composed of lines and points, this journey was made from an interpretation of the complexity and diversity of the dynamics of the Portuguese landscape, of the contrasts and similarities, and the objective was to know and feel the territory at a rhythm provided by latitudes of every ten kilometers in both lines [12]. With its starting points at Vila Nova de Cerveira on one side and Montesinho on the other, a mesh of points was formed that functioned as stopping places and registration-spots of the landscape, where the most representative images were gathered of this place, through a sensory diary which constituted the memory of the journey [13].

To speak of the landscape is to speak of a dynamic reality, of a process of transformations and interactions between different communities that share the same territory, as well as the speed at which they occur, so that, therefore, for its reading, it should integrate the different periods of time. As Nunes [29] tells us, regarding the interpretation of the landscape through these two paths (the "Two Lines"), it was possible to clearly understand the different speeds that occurred in the territory observed, as well as their relationship with the different ages signified by the landscapes. The contrast becomes evident when you roam through these "Two Lines": between a territory such as the coast, where the mechanisms of interaction between the communities and the environment are not only faster, but also denser; and a territory such as the interior, where these same mechanisms are processed at a much slower speed. The transformation of society is reflected as well in the landscape changes and, with it, in the contrasts between regions. For Nunes [29], and because the interpretation of the landscape relates to time and speed, the records will have to be made at various times, measuring the convergence and divergence of the processes in time, and calling for the establishment of an Observatory of the Landscape. To do this, the interpretation of the landscape could be made through imaginary lines that overlap the territory, lines which are little more than paths in the landscape, enabling its reading and interpretation, which will lead to the construction of a heritage that beams a better knowledge at the present and into the future, as well as allowing us to organize an archive of cultural and artistic dimensions [29]. Alves [2] also speaks of speeds, referring to the relationship of speed and the disconnection of the traveler with the space travelled (a characteristic of post-modern man), in which the speed imposed by technological development does not allow us the time to stop, think and ponder the true impact that it has on our relationship with people, things and the landscape. Likewise, it raises the following question: "To what extent does speed disconnect at the same time that it seeks to connect?" [2, 19]. The quick to very quick routes, made possible through the network of infrastructures built in recent decades, and present in the current road-plan, cross the territory in an indifferent manner to the area travelled and, sometimes, present a certain violence, a result of the speed with which they cross places, areas and landscapes. This violence is, to a certain extent, accepted as progress, but, as Alves [2] states, it sterilizes the life of the village. "The violence of speed - a slow hand caresses, a quick hand is a punch" $[2,22]$. However, this speed is not the one that best suits the ability to feel and enjoy the scenery.

For this purpose, the best way to connect with the landscape is walking. As stated by Schultz: "Walkers make use of all their senses, are involved with the whole body, and are sometimes exposed to exhaustion. The rhythm that characterizes the act of walking enables a complex of body and mind" $[38,7]$. The act of walking is associated with an art in which, as in dance, the pleasure is not in body movement, but rather in the sensations of the soul that are associated with it [37], and, to this end, the role of nature is fundamental. It provides matter for the walker when hiking in full nature, where man feels more human.

In fact, to know any landscape, one has to travel it on foot and feel it, and this is the most natural way to do so. When we walk, we are exclusively dependent on ourselves and completely freed to observe and appreciate the landscape as best suits us and with a complete tranquility $[37 ; 30]$.

The art of walking refers not only to physical exercise, as is generally understood. Frequent walks in the midst of nature are an opportunity for that nature to have a beneficial influence on man, to allow 
a deeper knowledge of the natural world, as well as to detect and observe the specificities of each landscape. Each one has its own character, a character that can only be unveiled through the insights triggered by each observer as he walks [43].

According to Schelle [37], the paths in the mountains inspire and nourish the mind. With tours through mountains and valleys, the spirit strengthens itself via the alternation between these morphological features, engendering different sensations and insights that contribute to the imagination. The diversity and the alternation contribute in a very positive way to the pleasure of walking. Walking along a path that rises up a mountain enables the unveiling of a landscape to the extent that, calmly, as one climbs up, pausing here and there, the slow unveiling of the landscape can create a special pleasure for the spirit. Petrarch's ascent of Mount Ventoux (1335) and Thomas Burnet's trips through the Alps are routes which are associated with cultural values - namely, the appreciation of nature and the origin of the aesthetic. As with ascents, descents also reveal the panorama in a particular aspect, and this panorama is always variable [37]. Such sensations and perceptions are only obtained when you walk. The speed of movement allows this unveiling little by little as you progress. To walk in a valley conveys different sensations depending on the configuration of the valley itself.

To hike in the landscape is also to be in contact with the fields, meadows and forests, and the reading of these landscapes is better achieved when we are close to them, in the midst of them, as opposed to when we see them from a distance. The fields, thanks to their variety and diversity throughout the year, almost always delight us, offering a rich palette of insights - whether a recently plowed field, whether a green field in the spring. A walk in a meadow or plain allows you to free your thoughts, in much the same way as a walk in some forests can convey an impression of romantic nature [37].

According to Thoreau [43], in walks through nature, there is a freedom of spirit that cannot be achieved in more artificialized places. The climate itself influences man, and, as is stated by Thoreau [43, 42-43], "(..) as I believe that there is something in the air of the mountain that inspires and nourishes the spirit. Will man not achieve greater intellectual and physical perfection under these influences? (...) I believe that we will be more imaginative, that our thoughts will be clearer, fresh and ethereal, as our heaven - that our understanding will be more comprehensive and wide, as our plains - I believe that our intellect will generally have wider proportions, as the thunder and lightning, our rivers, our mountains and forests, and that our hearts will resemble in length, depth and grandeur our continental seas".
It is from the woods, forests and wild nature that many poets and philosophers are 'born'. Hiking in nature inspires all kinds of artists, as their thoughts become nourished away from the multiplicity of movements and noises, often aggressive, which characterize the most artificialized spaces. The "wild thought" is, according to Thoreau [43, 56], the most beautiful "(...) that, among the dew which falls, rises higher over the wetlands (...)".

To hike in the landscape is also a form of art, an aesthetic experience which was manifested during the 20th century, although in different ways between the beginning and the end of the century. In the earlier decades, the act of walking was experienced as a form of anti-art, such as the wanderings of the Dadaist, which subsequently allowed artists to undertake their actions in real space [9]. It is this literary-artistic movement, led by writers and poets such as Hans Arp (1886-1966), Hugo Ball (1886-1927) and Tristan Tzarao (1896- 1963), that involves the representation of movement in the construction of an aesthetic action in real space, which is achieved through, for example, the act of walking [9].

In this primarily European experience, hiking in the landscape was related to ways of seeing and acting in reaction to the social, political and artistic paradigms of the time. Its character was fundamentally revolutionary.

By the 1920s, wanderings in a non-urban space had begun, in particular in open fields in the center of France. The routes were chosen at random and hiked by people who walked and talked simultaneously [9]. These were paths through non-urban landscapes whose space appeared as an active subject.

The relationship between the act of hiking in the landscape and artistic expression was, by the 1960s, assumed in America through Land Art. The walk was understood as an aesthetic practice, a physical modifier of space, and an instrument of knowledge of the landscape. In fact, the practice of walking often transforms itself into an art form, and a large number of artists, mostly sculptors, adhere to this form of artistic expression. As wanderings emerged as artistic forms, they also became linked to the literary field, most notably via André Breton (1896-1966) and Guy Débord (1931-1994). In Land Art, artists adopt this expression of art, through the act of walking, as a deep aesthetic experience, anchored to the visual arts (Rey, 2010). As explained by Richard Long (1945 - ), comparing his work to Carl Andre (1935 - ), his art is the very act of walking, hiking in the landscape, while the works of Carl Andre are sculptures on which it is possible to walk [9]. To hike in the landscape assumes different artistic expressions, either as the basis or origin of a work of art (an example of which is the work of Richard Long), or as a way to feel and see the artistic work (which can be achieved by walking on the works of art 
of Carl Andre). "A line made by walking" by Richard Long is no more than a line drawn on the ground, a result of the act of walking, leaving only the marks of his feet "sculptured" in the grass, which will disappear when the same grows. This work joins the art of sculpting (line) with the art of walking (the action), resulting in a unique work of art, whose formal simplicity and absolute radicalism is considered a masterpiece of contemporary artwork [34].

Another artistic approach related to the art of walking are the journeys made by Robert Smithson (1938-1973) who, in 1967, finished A Tour of Monuments of Passaic, the first trip through the empty areas of the urban peripheries, which allowed not only a different interpretation of the landscape, but also an understanding of its transformations [9].

The inspiration of, among others, thinkers, philosophers, writers and musicians, is strongly conditioned by the act of walking the landscape. Writing about the French writer Charles Péguy (1873-1914), Steiner states: "The phrases marching inexorably forward, their conclusions are hammered on target by the beat of those heavy walking shoes and boots of infantry soldiers symbolic of the vision of Péguy" [40, 30-31]. Similarly, the poet Samuel Coleridge (1772-1834) routinely walked thirty to forty kilometers per day through mountains and difficult terrains at the same time as he composed poetry. These were journeys of inspiration and creativity.

The act of walking and hiking in the landscape thus assumes different forms and different approaches, and it is indisputable that the inter-relationship established between man and the landscape he is hiking through is only possible through walking. This unique form of movement conveys a wealth of information about our identity, condition and destiny.

As Careri [9] states, the intrinsic characteristics of reading and simultaneous recording of space and landscape can lead to the act of walking transforming itself into an instrument, one which intervenes and generates interactions in the transformations of spaces and the landscape. Schultz [38] corroborates the idea that the simple act of walking generates knowledge and ideas. "(..) walking stimulates this process of perceiving, intuiting, and reflecting and, thus, is the best way to explore the area (...), and to generate ideas for large-scale landscapes" [38, 7].

\section{A growing interest: present motivations to walk in the landscape}

"I think that I cannot preserve my health and spirits, unless I spend four hours a day at least - and it is commonly more than that - sauntering through the woods and over the hills and fields, absolutely free from all worldly engagements." [42, 3].

The philosopher and writer Henry Thoreau, in his lecture given on 23 April 1851, foresaw the danger of a materialistic society as a consequence of the industrial revolution, as well as the destruction of the relationship between human beings and nature. The foresight of this collapse, accompanied by the expulsion of spirituality that natural spaces afford, was pinpointed by Thoreau, bringing attention to the fact that man becoming overly attached to civilization would lead to the loss of vital capacities, the degradation of vital instincts and the subsequent decline of civilization.

Effectively, the progressive changes and transformations that have been taking place in the landscape (particularly since the industrial revolution) and the ensuing pressures which have been placed on it have led to the misappropriation of resources, to the degradation of its spatial framework as a consequence of its exploitation, as well as to the deterioration of its visual quality.

Roads, motorways and railways have allowed a greater rapidity of flows, of movements of people between areas. Life is characterized by an increasingly accelerated pace - a pace which is clearly inappropriate when we take as reference the rhythms of nature (of which man is an integral part, though he seems to want to forget this).

On the one hand, walking begins to not make sense, because the walker's own pace is inconsistent with the pace that technological evolution seeks to impose. The speed with which travel occurs leads to a growing separation between the environment and man, as the necessary time to "feel", observe and think about the space and the landscape is not compatible with the speed at which man moves, or, at least, it is so in a very different way. The paths and roads have become almost fully occupied by motorized vehicles, and, in urban areas, the cross-sectional profiles of the streets have widened, with the consequent reduction (or, in some cases, absence) of space for pedestrians. This new reality of space allocated to the modern road-plan both in rural and urban environments discourages walking since, in addition to the need that man feels to move at an increasingly rapid pace, situations of conflict between the pedestrian and the car are beginning to make themselves felt in an increasingly pronounced manner. In this context, Caldeira Cabra galerts us to the need "(...) of the construction of footpaths to walk beside the main roads, which is already well established in many countries and is of great advantage to everyone, given the increasing speed of traffic" [7, 141].

After long decades of progressive growth, the increase of urban areas accentuates the separation between the city and the countryside, and the reduction of the presence of nature in urban spaces. The connection to the "earth" slowly and gradually disappears [6]. In fact, the 20th century was marked by a boom in the growth of urbanization, at a global level, in which a quarter of this growth occurred 
between 1950 and 1980 [27]. The cities were no longer "points" in the landscape, but encompassed wide areas and gave rise to a large concentration of people: communities who were and remain subject to an artificial life, one in which the use of material wealth quickly becomes confused with happiness or quality of life. As the quality of life in cities decreases, the urban society begins to suffer from living in an inhospitable environment where the presence of nature is not felt. This megalomaniac increase of the concentration of people in urban areas - the new Metropolis - has led to the abandonment of fields, and to the depopulation and desertification of rural areas [31], causing the destruction of natural areas and/or rural areas close to the cities. All of this has resulted in an increasing environmental imbalance in the industrialized world, and the need for the presence of nature and a diversified, humanized, balanced and biologically active landscape.

Environmental consequences, which have been intensifying on a par with technological growth, gave rise to the environmental movements that developed primarily from the 1960 s onwards, as well as increased interest in issues related to sustainable development and the preservation of the quality of the environment. At the level of the landscape and the environment, the concept of protection of nature was born. Thus, the first National Park appeared (Yellowstone National Park in the United States of America, nominated later, in 1976, as a biosphere reserve and, in 1978, classified as a World Heritage Site by UNESCO). This was the first milestone in the beginning of the development of an effective policy of protection of nature, whose philosophy was linked to aesthetic values. Following the creation of this park, several Natural Parks began to emerge in Europe whose philosophy exceeded simple aesthetic interests. A markedly ecological philosophy was assumed, with a view to the protection of certain species of plants and animals. This philosophy continued to evolve, assuming a fundamental role in the characterization and protection of ecological processes.

If the creation of National and Natural Parks was an important milestone in matters related to the protection and conservation of nature, at a later stage environmental organizations played a fundamental role in the continuity and, especially, in the consolidation of these policies of protection and conservation of nature. In this context, after the Second World War, the United Nations Educational, Scientific and Cultural Organization (UNESCO) was created, and in the follow-up of this policy, throughout the years several organizations emerged as well as diverse documentation. This occurred not just at an international level, but also at a national level: in the creation of the Network of Biosphere Reserves (1971); in the establishment of the United Nations
Environment Program (UNEP, 1972); in the Declaration of the Environment, drawn up at the United Nations Conference in Stockholm (1972); in the World Conservation Strategy (1980); in the Brundtland Report (late 1980s); in the Earth Summit held in Rio de Janeiro (1992); in the Lisbon Action Plan (the second European conference on sustainable cities) and its approval of "The Letter to Action" (1996); in The Kyoto Protocol (1997); in the Johannesburg Summit (2002).

However, those policies, related to the issues of nature conservation and protection, had quite a sectorial approach, one which did not focus on the landscape. It was at the end of the 20th century that the preparation of various documents also aimed at the landscape began: the Letter of Mediterranean Landscapes, in Seville, also known as the Letter of Seville (1994); the publication of the Strategy for the Conservation of Biological Diversity and the Landscapes (PEBLDS - Pan-European Biological and Landscape Diversity Strategy, 1995); and the European Landscape Convention (2000). In this perspective, the various currents of thought showed not only the concerns in relation to existing problems (such as disproportionate and megalomaniac growth without taking into consideration balance and ecological and landscape values), but also the ideologies that are related to them.

However, if, on the one hand, efforts were made to minimize the negative impacts that technological growth caused, on the other hand, society tried to find the biological and environmental balance that it was losing with these technological advances. In the late 20th century, we see the growing demand of rural areas, for they were the areas which most closely resembled natural space, both in terms of enjoyment and habitability [25]. This demand, mainly propounded by urban dwellers, gave rise to a diverse set of actions, declarations and resolutions, which held the aim of meeting the demands of the people (in particular as regards to outdoor activities) and providing more sustainable development in landscapes of quality - a key element of individual and social well-being, as understood in the physical, psychological and intellectual sense.

Following the concept of the Green Way in the USA in the 1960s, from the 1990s onwards there has been an expansion of Green Ways throughout Europe [11] - the European Green Ways Association (EGWA) was created, adopting the resolution of Logroño (1998). These Green Ways are paths through nature, identifying themselves as lines in the landscape, increasingly sought after by urban dwellers. In Europe, in the 1960s, the European Rambler's Association (ERA) was founded, and by 1971 it already included 14 organizations from six European countries. Currently, the ERA includes more than 55 organizations from 30 European countries and has more than three million individual members [16]. 
These numbers show us the strong adherence of people to this type of activity from the end of the 20th century, as well as the public demand for more naturalized areas for the practice of outdoor activities, specifically walking.

Initially, before the end of the 20th century, the European Rambler's Association was mainly concerned with the marking of 11 European longdistance paths across Europe (E-Paths) [15]. From a conference held in Strasbourg, the Declaration of Strasbourg (28 September 2001) was adopted, its main objectives: to draw, mark and maintain 11 European long-distance paths across Europe; to understand and protect the countryside in accordance with the principles of sustainable development; to know the history and culture of Europe, as well as promote the protection of heritage; to preserve the right of free access to the countryside while respecting the environment [15]. Its objectives were therefore equally oriented toward the European Union, the understanding between peoples, the preservation of nature and of the European cultural heritage, integrated in a sustainable development and contributing to the improvement of the quality of life of the people.

In some regions of Europe, the practice of marking footpaths has a history of more than 130 years [5]. The practice of walking is a difficult activity to calculate, in terms of the number of people that practice it, so there is no exact knowledge of the evolution of the number of practitioners throughout the ages. According to the records of practitioners in the national federations, the number of groups and associations organizing hiking, and also the number of activities related to walking, it is known that it is an activity in real progress. In France, in accordance to the Ministry of Health and Sports, the number of walkers reached five million in 2010 [44].

Among outdoor activities, and those related to nature tourism, walking has been highlighted as an activity in growth. In rural areas there has been an increased interest in new tourist products, including recreational activities. One of these activities is hiking, a factor which contributes to the progress of Rural Tourism [25].

The significant increase in adherence to outdoor activities, especially walking [18], which has been observed in recent decades, is an indication that people are looking for new ways of being in contact with nature.

It was at the end of the 20th century and the beginning of the $21 \mathrm{st}$ that a big boom in the implementation of pedestrian paths at the Portuguese national level occurred [35]. According to the Federation of Camping and Mountaineering of Portugal, at the beginning of the 21 st century there was an increase of approximately $40 \%$ of paths. The interest in this type of activity (hiking in nature), both in organized groups and individually, has been increasingly gaining supporters, which reflects the increasing demand, by man, for naturalized areas. The restorative effect of nature on man is, indeed, one of the fundamental aspects of this increased demand, mainly from the urban area. According to Grant et al [21], there are several studies which demonstrate that there are many benefits to our health associated with walking. Short regular walks can generate both mental and physical benefits, mainly if people walk in green spaces [21]. Outdoor recreation and, particularly, walking in the countryside, may be especially beneficial in promoting the general health of people [21; 36; 46]. Nowadays people walk for different reasons: to reduce stress levels; to escape from their daily lives and daily routines; to walk for pleasure and shared experiences; to provide the opportunity to socialize; to exercise; and to learn landscapes (to only mention but a few) $[21 ; 26 ; 46]$.

The demand of nature, as a way of escaping everyday life, is effectively the "return" to nature.

\section{Conclusions}

This reflection intends to discuss the relationship between hiking and the landscape throughout history, and to emphasize the importance of the act of walking, not only to feel and better understand landscapes, but also to highlight the importance of establishing a deep linkage with landscape for man's quality of life. Throughout history there have been different ways that man has connected to landscapes through walking: as a need (for shelter, for food, for spirituality); as an artistic manifestation; as a form of discovery, of investigation; to convey knowledge; $[3 ; 9 ; 22 ; 37 ; 39]$.

The progressive increase of urbanization causes a decrease in natural and rural areas, and man has become more and more disconnected from nature $[6 ; 27 ; 31]$.

In consequence, people, mainly urban people, are looking for new ways of being in contact with green areas, especially natural ones. During the last decades, we have seen an increase in the demand for outdoor activities $[26 ; 35 ; 44]$. Several studies prove that the contact, by hiking, with natural and / or green areas (especially walking in the countryside), is good for health - there are physical and mental health benefits, and nowadays people hike for many reasons $[21 ; 36 ; 46]$.

However, it seems that more benefits are derived from hiking in natural environments rather than urban environments [6]. According to literature, since the 18th century philosophers, thinkers and scientists have defended the importance of hiking in the natural landscape to develop their thoughts and their creativity [37; 43]. So, hiking in the natural landscape assumes a great importance in the maintenance of a healthy body and, mainly, a healthy mind - one which can and 
probably will contribute both to the development of the sciences and to the development of society.

It is important that we develop future research to improve our knowledge not only about the influence of walking in the natural landscape, related especially to the benefits it has on man's creativity, but also to improve the knowledge about how to combine modern life with the benefits of walking in nature. Also of increasing importance is the need to develop research about urban planning designs associated with walking in nature, including natural and green areas. Emphasis should be given to the inclusion of green and blue infrastructures in urban planning, ones which will allow human beings during their daily lives greater contact with natural spaces.

\section{References}

1. Ahern, J. Greenways as a planning strategy. Landscape and Urban Planning, 33, 1995, pp. 131-155.

2. Alves, M. Dromologia da rotunda. In P.C. Duas linhas, Lisboa: Nortpint, 2009, pp. 18-23.

3. Amato, J. On foot. A history of walking. New York: New York University Press, 2004, 333 p.

4. Braga, T. Pedestrianismo e percursos pedestres (Amigos dos Açores ed.). Pico da Pedra, Açores: Nova Gráfica, Lda., 2007,66 p.

5. Brandão, B. Avaliação da qualidade dos percursos pedestres homologados em Portugal. Estoril: Escola Superior de Hotelaria e Turismo do Estoril. 2012, 65 p.

6. Bratman, G., Daily, G., Levy, B., Gross, J. The benefits of nature experience: improved affect and cognition. Landsape and Urban Planning. 2015, 138 (pp. 41-50).

7. Cabral, F. Fundamentos da arquitetura paisagista. Lisboa: Instituto da Conservação da Natureza. 1993.

8. Camping and Montaineering Federation of Portugal, [online09/05/2018]. http://www.fcmportugal.com/Percursos.aspx.

9. Careri, F. Walkscapes. El Andar como práctica estética/Walking as na aestetic practice. Barcelona: Editorial Gustavo GILLI, sa.2002, 205 p.

10. Carrapatoso, S., Silva, P., Colaço, P \& Carvalho, J. Perception of the neighborhood environment associated with walking at recommended intensity and volume levels in recreation senior walkers, Journal of Housing For The Elderly, 2018, Vol. 32, NO.1, pp.26-38

11. Coelho, J. Arquitetura Paisagista e as vias verdes. A experiência da realização de estudos com vista à sua implementação na região do Algarve. Évora: Universidade de Évora. 2009, 133 p.

12. Costa, C. (2009). Moinhos ao vento. In: Duas linhas. Lisbon: Norprint, 2009, p.58-62.

13. Costa, P., \& Louro, N. Duas Linhas. Lisboa: Norprint. 2009, 224 p.

14. Davies, N. Who walks, where and why? Practioners' observations and perspectives on recreational walkers at UK tourist destinations, Annals of Leisure Reasearch, [online 2016] http://dx.doi.org/10.1080/11745398.2016.1250648

15. ERA. European Ramble Assotiation. [online 2013] www.era-ewv-ferp.com.

16. ERA. European Ramble Assotiation. [online 2018] www.era-ewv-ferp.com.

17. Fabos, J. Introduction to overview: the greenway movement, uses and potentials of greenways. Landscape and Urban Planning, 1995, 33, pp. 1-13.

18. Ferreira, G. Environmental education through hiking: a qualitative investigation. Environmental Education Research, 2006, pp.177-185

19. Gobster, P. Perception and use of metropolitan greenway system for recreation. Landscape and Urban Planning, 1995, 33, pp. 401-413

20. Gonçalves, J. Passo-a-passo. Percursos pedestres de Portugal. Lisboa: Fergráfica, S.A. 2003.

21. Grant, G., Machackek, K., Pollard N., Allmark, P. Walking, sustainability and health: findings from a study of walking for health group. Health and Social Care in the Community, 2017, 25(3), pp. 1218-1226

22. Gros, F. A Philosophy of walking. Verbo, London. 2015, $227 \mathrm{p}$

23. Jackson, J. Las carreteras forman parte del paisaje. (M. Puente, Trad.) Barcelona: Editorial Gustavo Gili, SL. 2011,47 p.

24. Kupidura, A., Luczewski, M., Home, R., \& Kupidura, P. Public perception of rural landscapes in land consolidation procedures in Poland. Land Use Policy, 2004, 39, pp. 313-319.

25. Leal, C. O turismo rural e a União Europeia. Uma realidade em expansão. Guia prático de investimento. Almedina, Lisboa, 2001, $260 \mathrm{p}$

26. Lee, H. Examining neighborhood influences on leisure-time walking in older Korean adults using an extended theory of planned behavior. Landscape and Urban Planning, 2016, 148 (pp.51-60).

27. Magalhães, M. Paisagem urbana e interface urbano-rural, In: Paisagem, Lisboa: Direção Geral do Ordenamento Rural e Desenvolvimento Urbano, 1994, p.99-120.

28. Nassauer Dayrell, J. E., \& Wang, Z. Perceptions of the view from the road. University of Michigan. Michigan: Minnesota Department of Transportation, 2006.

29. Nunes, J. Duas linhas. In: Duas linhas, Lisbon: Norprint, 2009, p.58-62

30. Nunes, J., \& Nunes, M. Pelos trilhos de Portugal. Lisboa: Edições Inapa, 2007, 159 p.

31. Ramos, A. As dinâmicas da paisagem rural. $\mathrm{PhD}$ thesis, Universidade Técnica de Lisboa, Instituto Superior Técnico, Lisbon, 2008, $242 \mathrm{p}$

32. Rey, S. Caminhar: experiência estética, desdobramento virtual. Porto Alegre Magazine, 2010, 17, p.107- 121.

33. Rodrigues, A. Os trilhos pedestres como uma actividade de lazer, recreio e turismo - uma análise exploratória ao mercado dos trilhos pedestres em Portugal. Revista de Turismo \& Desenvolvimento, 2006, 6, p. 83-94.

34. Roelstraete, D. Richard Long: A line made by walking. One Work Series Edictor Mark Lewis, London, 2010.

35. Sales, T. (2015). Percursos na Paisagem. PhD thesis, Universidade de Évora, Évora, 2015. 246 p. 
36. Sarkar, C.; Webster, C.; Ptyor, M.; Tang, D.; Melbourn, S.; Zhang, X.; Jianzheng, L. Exploring association between urban green, street design and walking: results from the Greater London boroughs. Landscape and Urban Planning. 2015, 143, p. 112-125.

37. Schelle, K. A arte de passear. Passeios de Verão ou de Inverno; na montanha, no campo ou na floresta; sozinho ou acompanhado. (D. C. Cabral, Trad.) Mira, Mem Martins: Publicações Europa América, 2008, 156 p.

38. Schultz, H. Designing large-scale landscape through walking, Journal of Landscape Architecture, Routledge, Taylor \& Francis Group [online2014] http://www.tandfonline.com/loi/rjla20)

39. Solnit, R. Wanderlust. The history of walking. New York: Penguin Group, Inc, 2000, 326 p.

40. Steiner, G. A ideia de Europa. (5th ed.). Lisboa: Gradiva, 2013, 55 p.

41. Stevenson, N. \& Farrell, H. Taking a hike: Exploring leisure walkers embodies experiences, Social and Cultural Geography, Taylor \& Francis, 2018, Vol.19, issue 4, 9.429-447.

42. Thoreau, H. Walking. Uses: Cricket House Books, 2010, 36 p.

43. Thoreau, H. Caminhada $1^{\text {a }}$ ed Lisboa: Antígona Editores Refractários, 2012, 86 p.

44. Tovar, Z. Pedestrianismo, percursos pedestres e turismo de passeio pedestre em Portugal. Master thesis, Escola Superior de Hotelaria e Turismo do Estoril, 2010, 144 p.

45. Wit, S. Let's walk urban landscapes. New pathways in design research. Conference review. Leibniz University Hanover. Journal of Landscape Architecture, Routledge, Taylor \& Francis Group. [online 2016.]. http://www.tandfonline.com/loi/rjla20

46. Wolf, I. \& Wohlfart, T. Walking, hiking and running in parks: a multidisciplinary assessment of health and well-being benefits. Landscape and Urban Planning, 2014, 130 p.89-103

\section{INFORMATION ABOUT THE AUTHORS:}

Teresa Lúcio Sales $\mathrm{PhD}$ at the University of Évora, Portugal (2015). Docent at the University of Algarve (Portugal), Department of Earth, Marine and Environmental Sciences, at the study program of Landscape Architecture. Academic and research interests: landscape architecture design, theory of landscape architecture, rural landscape (processes and dynamics in rural areas), participatory process, perception and landscape evaluation, pathways/hiking and its relations with landscape and human well-being. E-mail: mtsales@ualg.pt

José Castro Phd in Sciences, at University of Alcalá, Spain (2005). Docent at Polytechnic Institute of Bragança (Portugal). Academic and research interests: landscape ecology, integrated planning, Forest for Recreation and Tourism, Hardwoods with value for the rural landscape, Cartographic Modeling, multicriteria evaluation, nature-based tourism. E-mail: mzecast@ipb.pt


Faculty of Architecture of University of Lisboa. Has developed research in the areas of spatial planning, landscape perception, water resource management and urban vegetation. E-mail: gsaraiva@sapo.pt

Teresa Pinto-Correia PhD at the Institute of Geography, U. Copenhagen, Denmark (1993). Docent at the University of Évora (Portugal). Director of the EU Institute for Agrarian and Environmental Sciences (ICAAM), University of Évora. His research is in the areas of rural landscape dynamics and management, relations between agriculture and landscape, landscape multifunctionality, transitional processes in rural areas, multi-level management policies and decisions, and relations of decision-makers and users with the landscape. E-mail:mtpc@uevora.pt

Kopsavilkums. Jau no seniem laikiem cilvēks ir veicis pārgājienus ainavā, izveidojot savstarpēju savienojumu starp diviem vai vairākiem punktiem. Pārgājieni pa takām ir cilvēka aizbēgšanas līdzeklis, kas izraisa pārmaiņas ainavā un izplata jaunas vietas. Rakstā ir atspoguḷota dinamika, kas izveidojusies starp cilvēku un ainavu, kā arī sabiedrības pārmaiņas (pārsvarā kopš 18. gadsimta). Dabas taku pastāvēšana ir vecāka par pašas cilvēces eksistenci. Konkrētā darbība vienmēr ir bijusi saistīta ar cilvēka vēsturi ainavā, kas meklēja pārtiku, veica svētceḷojumus, tūrismu, veselīgu atpūtu un iedzīvotāju dz̄̄ves kvalitātes uzlabošanos. Kad mēs staigājam, mēs esam tikai atkarīgi no sevis un pilnīgi brīvi spējam novērot un novērtēt ainavu, kas vislabāk atbilst mums, iegūstot mieru. Pārvietošanās, pastaigas ainavā ir labākais veids, kā uztvert un veidot ciešas attiecības ar ainavu. Mūsdienās ievērojami palielinās aktivitātes ārtelpā, īpaši pastaigas. Cilvēki meklē jaunus veidus, kā sazināties ar dabu. Dabas atjaunojošais efekts uz cilvēku patiešām ir viens no šī pieaugošā pieprasījuma pamatā esošajiem aspektiem un cilvēki staigā dažādu iemeslu dēḷ. Nepieciešams veikt arī turpmākus pētījumus par cilvēku pastaigu sasaisti ar ainavu un ieguvumiem, ko sniedz pastaigas dabā. 